ANNALES

POLONICI MATHEMATICI

XVI (1964)

\title{
In Memory of Witold Pogorzelski
}

\author{
by J. Wolska-Bochenke and A. Piskorek (Warszawa)
}

Witold Pogorzelski died in Warsaw on 3rd January, 1963. He was professor in ordinary and head of the Chair of Mathematics at the Warsaw Institute of Technology, head of the Department of Integral Equations at the Mathematical Institute of the Polish Academy of Sciences, member of the editorial committee of "Annales Polonici Mathematici", member of the Central Board of the Polish Mathematical Society and Chairman of the Warsaw Branch of the Polish Mathematical Society.

Witold Pogorzelski was born in Warsaw on 13th October, 1895. As a mere child, he impressed his family and friends with his perspicacity and excellent memory. He had a good ear and was keen on learning music; he was also interested in plastic arts. Quiet and thoughtful by disposition, he was extremely sensitive and had a deep-rooted love of truth. These two qualities formed the leading traits of his character. All through his life, he was sincere, unaffected and unassuming. He began his education at the Chrzanowski Highschool in Warsaw; he then attended the Stanisław Staszic School. It was as a senior pupil of that school that he first revealed his extraordinary aptitude and keenness for mathematics. He studied, on his own, branches of mathematics which went far beyond the school syllabus.

Graduates of the Stanisław Staszic School were given no admission to the universities in the Russian-governed part of Poland. Accordingly, Witold Pogorzelski went to France and studied at the universities of Nancy and Paris, where, in 1914, he was granted the degree of Licentiate of Science.

On his return to Poland he continued his studies at the Jagellonian University in Cracow. In addition, he took up teaching and research. In 1919 he was granted the degree of Doctor of Philosophy on submitting to the Philosophical Faculty of the Jagellonian University a thesis on Non-linear Integral Equations. Two years later, at the same university, he received the title of docent in mathematical physics. In the academic year 1920/21 he lectured in mathematical analysis at the Warsaw Insti- 
tute of Technology and at the Polish Free University (Wolna Wszechnica Polska), and in 1925 was appointed professor extraordinary, succeeding to the Chair of Mathematics at the Mechanical and Electrical Faculties of the Warsaw Institute of Technology. He held this post until the outbreak of Second World War, carrying out a vigorous pedagogical and scientific activity. In the same period he lectured in selected branches of mathematics and physics at the University of Warsaw.

In 1937 he was nominated professor in ordinary and elected to the Academy of Technical Sciences. During the war of 1939-1944 he went on lecturing and teaching at secret tutorial groups of the University of Warsaw, continuing this job with courage and devotion, in constant danger-especialy in Warsaw-of repressions from the occupant, until the Warsaw uprising.

Soon after the liberation of the country, Witold Pogorzelski joined in the work of reconstruction and rehabilitation of Polish universities. He organized, with spirit and energy, the department of mathematics at the newly-founded Technical University of Eódz. He then returned to the Warsaw Institute of Technology, which was in the process of rebuilding and reorganization, and resumed his post as head of the Department of Mathematics at the Faculties of Mechanics and Electricity. Until 1951 he also lectured in selected branches of mathematical analysis at the Faculty of Mathematics, Physics and Chemistry of the University of Warsaw. Moreover, since June 1949 he was engaged in research work at the State Institute of Mathematics, directing, in collaboration with professor W. Rubinowicz, the section of Mathematical Problems of Physics. Since 1950 he directed the Integral Equations Section of that institute. Soon the research work at the Institute absorbed him almost entirely. The Integral Equations Section grew into an important and very active scientific centre at the Institute of Mathematics.

However, in spite of his being fully occupied with his work at the Warsaw Institute of Technology and at the Institute of Mathematics, Witold Pogorzelski, aware of the enormous importance of mathematics in medern military sciences, took upon himself the organization, in 1951, of the Department of Mathematics at the newly-founded Jarosław Dąbrowski Military Technical Academy and headed that department for five years. It should be emphasized that even after his resignation from that post he collaborated with the Military Academy in scientific matters and superintended the training and research work of younger members of the staff of the Department of Mathematics in that school.

In 1961 the Technical University of Eódź conferred upon Witold Pogorzelski in recognition of his services the degree of Doctor Honoris Causa. 
The last fifteen years of his life were spent on research, the outcome of which were nearly a hundred scientific publications appearing in Poland and abroad. Their list is appended at the end of this article.

The research work of Witold Pogorzelski centred on integral equations and their application to boundary problems of analytic functions and to the theory of partial differential equations of the parabolic, elliptic and hyperbolic types. This range of subjects is a clear evidence both of his deep interest in physics, technology and natural sciences in general and of his conviction that the fundamental object of mathematics is to investigate the phenomena of the world around us.

In the works of Witold Pogorzelski, side by side with the methods of classical mathematics, we find the methods and theorems of modern mathematics, which he always regarded as the source of powerful tools and theoretical devices in mathematical investigations.

His earliest papers [3], [6] in the field of integral equations, were published in 1918; they deal with a certain type of non-linear integral equations. He investigates in them the problem of solvability of this type of equations. The second of the two papers constitutes his doctor's thesis, which he submitted to the Philosophical Faculty of the Jagiellonian University in 1919. In 1920 Witold Pogorzelski took up the investigation of strongly singular integral equations; two years later he published a paper [11] in this field and shortly afterwards another one [13]. The two papers, probably the first Polish papers on the subject published in those days, are pioneer in character. Witold Pogorzelski discusses in them the complicated problem of solvability of singular non-linear integral equations and generalizes the Poincaré-Bertrand transformation to non-analytic functions. This problem is also dealt with in one of his later papers [22], published in 1939 in the periodical "Journal de Mathématiques" in a volume dedicated to $\mathrm{J}$. Hadamard.

The outbreak of Second World War and the events which followed interrupted Witold Pogorzelski's scientific activity. He resumed it after the liberation of the country and continued his research in the three domains mentioned above. In his papers published after the war he examines the existence of solutions of singular integral equations under much more general assumptions, in the class of functions satisfying the Hölder condition. The results of these investigations appear in papers [24], [28], [29], [38], [39], [41].

In the above-mentioned class it has been impossible to give proofs of the existence of solutions of singular integral equations by methods of classical analysis. Accordingly, Witold Pogorzelski makes use of modern methods, based on the theorems of topology and of functional analysis. He uses in his investigations the fixed point method, based on the topological theorem of J. Schauder. A great many boundary 
problems in the theory of analytical functions reduce to singular integral equations, for example the Hilbert-Riemann problem. Witold Pogorzelski formulates and investigates this problem in the non-linear case using the theorem of J. Schauder.

Then, under the influence of certain ideas due to the eminent Soviet mathematician N. J. Mushelishvili, W. Pogorzelski studies the boundary problems of analytic functions with discontinuous limit functions. He introduces a new class of discontinuous complex functions defined on a system of open ares and calls it class $\mathfrak{h}$.

The investigation of the properties of functions of this class, in particular the properties of the integral of the Cauchy type for a system of arcs, is a difficult task, requiring a great deal of precision and inventive power. The fundamental result of these investigations is the theorem stating that the Cauchy formula transforms class $\mathfrak{G}$ into itself. This result and several other results concerning class $\mathfrak{5}$ were published in papers [53], [54], [55], [56], [59], [60].

The next important achievement of Witold Pogorzelski in this domain is the introduction of the class of holomorphic functions with dis. continuous limit functions of class $\mathfrak{H}$. Functions of this class occur in non-linear boundary problems with discontinuous limit functions, which were a subject of his investigations [68], [70], [75], [87].

Witold Pogorzelski then concerns himself with strongly singular integrals in a multi-dimensional space. He obtains interesting results concerning their regularity and introduces a class of discontinuous functions in an $n$-dimensional space. He proves the fundamental theorem for functions of this class, stating that a transformation defined by a strongly singular multidimensional integral transforms this class into itself. On the grounds of this property, he investigates the existence of a solution of a system of strongly singular integral equations in space, using J. Schauder's topological theorem on the fixed point. These results appeared in the memorial volume published in the Soviet Union on the seventieth birthday of $\mathrm{N}$. J. Mushelishvili and in other papers ([76], [77], [78], [81], [82]).

To complete the account of this part of Witold Pogorzelski's scientific heritage, it should be mentioned that his results, particularly in the field of strongly singular integral equations connected with the boundary problems of the theory of analytic functions, are quoted by N. J. Mushelishvili.

Witold Pogorzelski's work on applications of integral equations to the theory of partial equations has given rise to over 50 publications, appearing at home and abroad. It would be difficult to give a full account of that work; of necessity we must confine ourselves to discussing a few selected papers. 
His earliest results in this domain concern partial equations of the elliptic type. In 1922 he published a paper [11] on investigating the resolvent kernel of an integral equation, which is obtained by means of the theory of Newtonian potential for the third boundary problem in a given region. His next papers deal also with harmonic functions in given regions; namely, they concern boundary problems with tangential derivatives in a given region. The problem of tangential derivatives posed by $H$. Poincaré consists in determining in a given region a harmonic function which satisfies on its boundary a given linear relation between the values of the derivatives in the directions of the normal and of the tangent to the boundary. The papers in questions [18], [21] appeared in 1936 and 1938 respectively. In the second of them Witold Pogorzelski gave an essential generalization of the problem posed by H. Poincaré, postulating that a harmonic function inside a domain bounded by a closed analytic curve should satisfy a boundary condition expressed by a linear relation between the derivative along the normal, the derivative along the tangent and the function itself, under the assumption that the coefficients in that linear relation are analytic. In the problem posed by $H$. Poincaré only the relation between the derivative along the normal and the derivative along the tangent to the boundary was given. Pogorzelski's generalization has affected in an essential way the method of solution. In consequence of seeking a harmonic function satisfying the given boundary condition the problem has been reduced to a strongly singular integral equation.

After the war Witold Pogorzelski continued his research into the problem of tangential derivatives and in $\mathbf{1 9 5 5}$ published a paper [45] containing several generalizations of his earlier results. In view of the progress achieved in the investigation of this problem, mainly owing to the work of the Soviet mathematicians B. W. Hvedelidze and J. N. Wekua, the assumptions regarding the coefficients occurring in the boundary conditions have been weakened considerably instead of analycity only the Hölder condition is now being assumed. The boundary condition, taken by other authors, in the form of a linear relation, is expressed in paper [45] of Witold Pogorzelski by a non-linear relation between the derivative along the normal, the derivative along the tangent and the function itself. The method of solution is based on the fixed point theorem of J. Schauder.

Further generalizations of Poincaré's problem of tangential derivatives to the case of an elliptic equation with variable coefficients in an $n$-dimensional space and the boundary condition concerning $k$ fields of the directions tangent to the boundary of the given region required determining the fundamental solution of that equation and investigating the tangential derivatives of the generalized potential of a simple layer 
with respect to that equation. The results of those investigations were published by Witold Pogorzelski in papers [37], [43], [66], [67], [74], [84], [85]. It should be mentioned that the construction of the fundamental solution for the general equation of elliptic type has been carried out-on the basis of the idea of Levi-under wery weak assumptions, namely that the coefficients of this equations satisfy the Hölder condition only.

In paper [84] Witold Pogorzelski considers $k$ fields of vectors tangent to the surface bounding a given $n$-dimensional region and formulates a generalized non-linear problem of tangential derivatives for the general elliptic equation; he solves this problem under very weak assumptions, using the fixed point theorem of J. Schauder.

An important part of Witold Pogorzelski's scientific output are his papers concerning parabolic equations, a particular case of which is the heat equation. His first work in this field is paper [27], published in 1951, in which, with the aid of the heat potential of a simple layer, the solution of the third problem of Fourier for the heat equation with a homogeneous initial condition is reduced to the solution of a Volterra integral equation. Witold Pogorzelski obtains the solution of that equation by the classical method of successive approximations, the solution having a global character in the time interval and being determined with no restrictions as to the size of the space region with a boundary which is a Lapunov surface. At the time of its publication the work in question constituted a considerable generalization of the results obtained by H. Müntz and S. G. Michlin.

The next paper [31] presents a solution of the third non-linear problem of Fourier in the case of heat sources non-linearly dependent on temperature acting inside the space region, the expression of which is the right side of the partial equation occurring in this problem. The right side of this equation is a function in three arguments of a point, of the time variable and of temperature; the left side contains the partial operator occurring in the heat equation. In the paper in question, Witold Pogorzelski reduces the solntion of the above problem, with the aid of heat potentials, to the solution by the fixed point method of a nonlinear system of Volterra integral equations, basing himself on J. Schauder's theorem.

In paper [42], under the influence of Levi's idea, Witold Pogorzelski constructs the fundamental solutions of the parabolic equation in normal form with variable coefficients, assuming that the coefficients of the characteristic form of this equation satisfy the Hölder condition with respect both to the time variable and to the space variables and that the remaining coefficient are continuous and satisfy the Hölder condition only with respect to the space variables. Paper [42], which was 
a fundamental importance for further investigations, was followed by a series of publications starting with paper [46]. In this and the following papers [47], [64] the author constructs with the aid of the fundamental solution three solutions of the parabolic equation in question, calling the first the Poisson-Weierstrass integral and the remaining two, respectively, the generalized potential of a volume and the potential of a simple layer with respect to that equation. He then investigates the differentiability of these solutions and the boundary properties, particularly of the simple layer potential and its derivatives. The most important of those properties is the theorem on the jump of the transversal derivative of the simple layer potential in passing from the interior. of a region to its boundary. This theorem links together the theory of integral equations and the theory of problems containing in the boundary condition the limit values of the transversal derivative. Another subject of research in this series of papers is the problem of regular continuity of solutions and their derivatives in bounded and unbounded regions. These properties are applicable in an essential manner to the solutions of boundary problems by the fixed point method.

In the next, long series of publications, starting from papers [50], [58], Witold Pogorzelski, using the fixed point mothod based on J. Schauder's theorem, carries out the proofs of existence of solutions of boundary problems for semi-linear equations of parabolic type. These problems are generalizations either of the Fourier problem or of the Poincare problem, since the boundary conditions occurring in them form a nonlinear relation connecting the limit values of the transversal function of the required function either with the limit values of that function or with the limit values of its tangential derivatives. Moreover, this series of papers includes further generalizations of the results obtained; they are contained in papers [51], [52], [61]. The author proves by means of the fixed point method the existence of solutions of the first problem and of the generalized third problem of Fourier for the quasi-linear parabolic equation. Papers [72], [73] conclude this series of publications. In these two papers the author uses potentials derived from density unbounded close to the boundary, which enables him to give by the fixed point method the proofs of existence of solutions of the problems posed under the most general assumptions, admitting the unboundedness of the given functions. In both papers semi-linear parabolic equations of the second order are considered.

Witold Pogorzelski did not confine himself to investigating parabolic equations of the second order. In 1958 he published a paper [57], in which, basing himself on the investigations of $I$. G. Petrovski and the Gelfand-Shilov theorem, he gives a construction of the matrix of the fundamental solutions for a system, parabolic in the sense of Pe- 
trovski, of $N$ partial equations of order $M$ under the assumption that the coefficients of that system satisfy the Hölder condition. The method of construction is roughly the same as the method used in constructing the fundamental solution for the parabolic equation of the second order. This result, since it assumes the regularity of the coefficients of the system, is much more general than the result obtained by Eidelman in 1956.

The above paper is followed by a series of publications devoted to the investigation of the properties of the solutions of the system in question, analogous to the Poisson-Weierstrass and the remaining potentials of the theory of the parabolic equation. This series comprises papers [62], [63], [71], [88], [91] and ends with paper [92], in which Witold Pogorzelski investigates the non-linear boundary problem for a semilinear system of equations of parabolic type in the sense of Petrovski, using the fixed point method.

On the subject of partial equations of hyperbolic type Witold Pogorzelski published two papers [23], [25], in which he investigated the properties of a certain solution of the wave equation, called the retarded potential, and then discussed a certain mixed problem for the telegraphic equation. In the last few years of his life, while preparing the fourth volume of the monograph Integral equations and their applications, Witold Pogorzelski interested himself in equations of a mixed, hyperbolic-elliptic type. This is shown in the original treatment of the material of Chapter 25 of the above-mentioned monograph. To end up this survey of his works in the theory of partial equations, it should be mentioned that in all the publications discussed above the author makes ample and elegant use both of Fredholm and of Volterra integral equations.

There is a close connection between the above-mentioned scientific contributions of Witold Pogorzelski and his research work in physical and technical applications. He has published several papers in this domain. They first appear at the start of his scientific production and later alternate with purely theoretical works.

In papers [1], [2], [4], [8], [9], [14], concerning the physics of the atmosphere and the stratosphere, the author deals with the gradient of temperature, the velocity of sound, air motion close to the earth and fluctuations of temperature in the stratosphere. These papers were written at the beginning of his scientific activity.

The series of papers [10], [15], [16], [33], [36] deal with the theory of radiation. Witold Pogorzelski examines the distributions of temperature in radiating media and describes the motion of a radiating gas. The next set are papers [12], [26]. The first of them concerns the theory of electric superconductivity of metals and the second-the solutions of the Maxwell equations. The problem of safety of construction is tack- 
led in three of Witold Pogorzelski's papers. The first of those [19] dealt with the probability of shooting down a flying object when its velocity is considered. The second [20] presented the probabilistic approach to the estimation of the so called safety factor of a construction. The last paper [40] in this field gave a generalization of the results of the preceding one by the use of random functions.

Witold Pogorzelski's last work, finished in manuscript a few days before his death, is devoted to a certain problem of a dynamic system excited by stochastic random forces. It presents a beautiful application of the results obtained by the author in the theory of parabolic equations.

A separate part of Witold Pogorzelski's writings are his textbooks. Throughout his intensive pedagogic and scientific activity he published twelve textbooks for students of technical universities, engineers and mathematicians doing research in the domain of integral and partial equations. It is particularly worthy of note that in the last ten years of his life Witold Pogorzelski took upon himself the strenuous task of writing a four volume monograph entitled Integral equations and their applications and finished it shortly before his unexpected death. This work, in view of its uniqueness and the wealth of material contained in it, is now being translated into English for the publishing house Pergamon Press, although the last volume of the book, which the author handed in at the Państwowe Wydawnictwo Naukowe (State Scientific Publishers) one month before his death, has not yet appeared in Polish.

The results obtained by Witold Pogorzelski are quoted both at home and abroad. It should be stressed that his results in the field of partial equations of parabolic type have provided the basis for the investigation methods of the American mathematicians Friedman and Aronson and the Soviet mathematicians Maslennikov and Kamynin.

Witold Pogorzelski was well known for the kindly interest which he took in the careers of young scientific workers. He was always ready to help, encourage and advise them, he was tolerant and understanding, he delighted in all their successes. He went through all their manuscripts, helping to improve and develop every new idea. His influence upon the course and progress of research was considerable. The patronage which he extended to young scholars may serve as a model and an example.

The results of Witold Pogorzelski were a basis and an inspiration for the research of a large number of his pupils and collaborators. In the last fifteen years of his life he took charge of the doctorates of eighteen of his pupils; five of them obtained the degrees of docent and one the title of professor. 
In recognition of his outstanding services Witold Pogorzelski was awarded several high state distinctions: the Grold Cross of Merit, the Commandorial Cross of the Order of the Restitution of Poland and the Commandorial Cross with a Star.

With his death Polish mathematics lost an eminent scholar and a brilliant teacher.

\section{LIST OF PUBLICATIONS OF WITOLD POGORZELSKI}

[1] Badania teoretyczne ilości ciepla otrzymywanego przez Ziemie, Sprawozd. Tow. Nauk. Warsz. (1916).

[2] Przyczynek do teorii przemian adiabatycznych powietrza nasyconego para wodna, Sprawozd. Tow. Nauk. Warsz. 1 (1917), pp. 47-66.

[3] O pewnym typie równań calkowych i calkowo-różniczkowych nieliniowych, Wiadomości Matematyczne 22 (1918), pp. 155-166.

[4] Z teorii ruchów prostoliniowych w atmosferze, Sprawozd. Tow. Nauk. Warsz. (1917).

[5] $Z$ teorii ruchów poziomych powietrza, Sprawozd. T.w. Nauk. Warsz. (1917).

[6] O równaniu calkowym w teorii równowagi promieniowania, Sprawozd. Tow. Nauk. Warsz. (1918).

[7] Zagadnienie równowagi promieniovania $i$ inwersja temperatury, Sprawozd. Tow. Nauk. Warsz. (1917).

[8] O temperaturze stratosfery, Sprawozd. Tow. Nauk. Warsz. 5 (1918), pp. 725-734.

[9] Przyczynek do teorii ruchów gazu, Sprawozd. Tow. Nauk. Warsz. 8 (1917), pp. 921-938.

[10] Problème de Fourier pour le milieu rayonnant, Bibl. Univ. Lib. Pol. 1 (1922), pp. 1-5.

[11] Les propriétés du noyau résolvant de l'équation intégrale d'un problème aux limites, Bibl. Univ. Lib. Pol. 1 (1922), pp. 6-16.

[12] O teorii przewodnictwa elektrycznego $i$ cieplnego metali $i$ dielektrykoww, Bull. Acad. Pol. Sc. Techn. (1922), pp. 79-95.

[13] O równaniach calkowych z osobliwościa biegunowa, Sprawozd. Warsz. Tow. Politechn. 3 (1924), pp. 1-18.

[14] Sur la théorie de la stratosphère, Państw. Inst. Meteorolog. Warszawa (1922), pp. 1-22.

[15] Teoria promieniowania i kwantów energii, Państw. Inst. Meteorolog. Warszawa (1925), pp. 1-84.

[16] Problème de Fourier pour une couche rayonnante, Ann. Acad. Pol. Sc. Techn. (1934). 
[17] O ukladach wielkości elektromagnetycznych, Ann. Acad. Pol. Sc. Techn. (1935).

[18] Problème aux limites de $\boldsymbol{H}$. Poincaré, Ann. Acad. Pol. Sc. Techn. (1936).

[19] Recherches sur le problème de probabilité du tir contre l'avion, Ann. Acad. Pol. Sc. Techn. (1938).

[20] Sur une application du calcul des probabilités au tir de chasse, Ann. Acad. Pol. Sc. Techn. (1939).

[21] Über die Transformationen einiger iterierten uneigentlichen Integrale und ihre Anwendung zur Poincaréschen Randwertaufgabe, Math. Zeitschr. 44 (1939), pp. 427-444.

[22] Sur une équation intégrale de premiére espéce, Journal de Mathématiques, Paris, 1939, pp. 97-103.

[23] Sur les propriétés du potentiel retardé, Prace Mat. Fiz. 47 (1949), pp. 61-66.

[24] Le noyau singulier fermé, Prace Mat. Fiz. 48 (1952), pp. 105-110.

[25] Remarques sur un problème mixte concernant l'équation des télégraphistes, Prace Mat. Fiz. 48 (1952), pp. 59-66.

[26] Contribution á la théorie du champ éléctromagnetique, Prace Mat. Fiz. 48 (1952), pp. 53-58.

[27] Sur la solution de l'équation intégrale dans le problème de Fourier, Ann. Soc. Pol. Math. 24 (1951), pp. 56-74.

[28] Sur l'équation intégro-différentielle non linéaire à singularité polaire, Ann. Soc. Pol. Math. 24 (1951), pp. 75-87.

[29] Sur l'équation intégrale non linéaire de seconde espèce à forte singularité, Ann. Pol. Math. 1 (1954), pp. 138-148.

[30] Zagadnienie nieliniowe Hilberta-Priwatowa, Biul. Wojsk. Akad. Techn. 6 (1953), pp. 3-12.

[31] Sur le problème généralisé de Fourier, Ann. Pol. Math. 3 (1956), pp. 126-141.

[32] Prawdopodobieństwo bezpieczeństwa konstrukcji, Zastosow. Mat. 2 (1954), pp. 46-61.

[33] Równania ruchu gazu promieniujacego, Biul. Wojsk. Akad. Techn. 1 (1954), pp. 25-106.

[34] O pewnych zagadnieniach brzegowych w teorii potencjalu, Biul. Wojsk. Akad. Techn. 18 (1955), pp. 17-24.

[35] Badanie równań calkowych osobliwych metoda punktu niezmienniczego, Biul. Wojsk. Akad. Techn. 18 (1955), pp. 3-85.

[36] Problème du mouvement stationnaire dans une couche gazeuse rayonnante, Ann. Pol. Math. 1 (1955), pp. 367-378.

[37] Les propriétés d'une fonction de Green et ses applications aux équations elliptiques, Ann. Pol. Math. 3 (1956), pp. 46-75. 
[38] Sur le système d'équations intégrales à une infinité de fonctions inconnues, Ann. Pol. Math. 2 (1955), pp. 106-117.

[39] Problème non linéaire d'Hilbert pour le système de fonctions, Ann. Pol. Math. 2 (1955), pp. 1-13.

[40] Probabilité de la sécurité des constructions mécaniques, Bull. Acad. Pol. Sc. 2 (1954), pp. 363-366.

[41] Problème aux limites d'Hilbert généralisé, Ann. Pol. Math. 2 (1955), pp. 136-144.

[42] Étude de la solution fondamentale de l'équation parabolique, Bull. Acad. Pol. Sc. 4 (1956), pp. 9-13.

[43] Étude de la solution fondamentale de l'équation elliptique et des problèmes aux limites, Ann. Pol. Math. 3 (1957), pp. 247-282.

[44] Étude de la solution fondamentale de l'équation parabolique, Ricerche Mat., Napoli, 5 (1956), pp. 25-57.

[45] Problème aux limites de Poincaré généralisé, Ann. Pol. Math. 2 (1955), pp. 257-270.

[46] Propriétés des intégrales de l'équation parabolique normale, Bull. Acad. Pol. Sc. 4 (1956), pp. 407-410; Ann. Pol. Math. 4 (1957), pp. 61-92.

[47] Propriétés des dérivées tangentielles d'une intégrale de l'équation parabolique, Ricerche Mat., Napoli, 6 (1957), pp. 162-194.

[48] Wlasności potencjatów cieplnych w teorii równania przewodnictwa, Biul. Wojsk. Akad. Techn. 29 (1957), pp. 3-42.

[49] Problème aux limites pour l'équation elliptique dont les coefficients dépendent de la fonction inconnue, Biul. Wojsk. Akad. Techn. 29 (1957), pp. 43-62.

[50] Problèmes aux limites pour l'équation parabolique normale, Ann. Pol. Math. 4 (1957), pp. 110-126.

[51] Problème aux limites pour l'équation parabolique dont les coefficients dépendent de la fonction inconnue, Ricerche di Mathematica 5 (1956), pp. 258-272.

[52] Etude d'une fonction de Green et du problème aux limites pour l'équation parabolique normale, Ann. Pol. Math. 4 (1958), pp. 288-307.

[53] Propriétés d'une intégrale singulière pour les arcs non-fermés et leur application, Bull. Ac. Pol. Sc. 6 (1958), pp. 85-87.

[54] Sur l'équation intégrale singulière non linéaire et sur les propriétés d'une intégrale singulière pour les arcs non-fermés, Journal of Mathematics and Mecanics, Indiana University, 7 (1958), pp. 515-532.

[55] Remarques concernant le travail: sur l'équation intégrale singulière etc., Journal of Mathematics and Mecanics, Indiana University, 8 (1959), pp. 159-160.

[56] Sur certaines classes de fonctions complexes définies sur les arcs non-fermés, Bull. Ac. Pol. Sc. 7 (1959), pp. 57-62. 
[57] Etude de la matrice des solutions fondamentales du système parabolique d'équations aux dérivées partielles, Ricerche Mat., Napoli, 7 (1958), pp. 153-185.

[58] Problème aux limites aux dérivées tangentielles pour, l'équation parabolique, Ann. Ecole Norm. Sup., Paris, 75 (1958), pp. 19-35.

[59] Sur les équations intégrales résolubles sans limitations et leur applications aux équations différentielles, Journal de Mathématiques, Paris, 37 (1958), pp. 21-40.

[60] Problème généralisé de Hilbert pour les arcs non-formés, Ann. Ec. Norm. Sup., Paris, 75 (1958), pp. 201-222.

[61] Premier problème de Fourier pour l'équation parabolique dont les coefficients dépendent de la fonction inconnue, Ann. Pol. Math. 6 (1959), pp. 15-40.

[62] Propriétés des solutions du système parabolique d'équations aux dérivées partielles, Mathematica Scandinavica 6 (1958), pp. 237-262.

[63] Propriétés des intégrales généralisées de Poisson-Weierstrass et problème de Cauchy pour un système parabolique, Ann. Sc. Ec. Norm. Sup., Paris, 76 (1959), pp. 125-149.

[64] Исследование интегралов параболического уравнения и краевых задач в неограниченой области, Матем. Сбор. (47), (89) (1959), pp. 397-430.

[65] Problème aux limites dans un domaine non borné pour une équation parabolique dont les coefficients dépendent de la fonction inconnue, Biul. Wojsk. Akad. Techn. 47 (1959), pp. 26-45.

[66] Propriétés des dérivées tangentielles d'une intégrale de l'équation elliptique, Ann. Pol. Math. 7 (1960), pp. 321-339.

[67] Problème aux limites dérivées tangentielles pour l'équation elliptique, Bull. Acad. Pol. Sc. 7 (1959), pp. 205-212.

[68] Problèmes aux limites discontinues dans la théorie des fonctions analytiques, Bull. Acad. Pol. Sc. 7 (1959) pp. 311-317, Journal of Mathematics and Mecanicis (9), (4) (1960), pp. 583-606.

[69] Sur la résolution du problème aux dérivées tangentielles pour l'équation parabolique par la méthode des approximations successives, Ann. Pol. Math. 7 (1959), pp. 93-112.

[70] Propriétés d'une classe de fonctions holomorphes aux fonctions limites discontinues, Ann. Pol. Math. 9 (1960), pp. 189-200.

[71] Sur la continuité régulière des dérivées d'ordre maximum des intégrales généralisées de Poisson-Weierstrass relatives au système parabolique, Bull. Acad. Pol. Sc. 8 (1960), pp. 751-755.

[72] Sur certaines propriétés des intégrales de l'équation parabolique et un problème aux limites, Bull. Acad. Pol. Sc. 8 (1960), pp. 53-58.

[73] Problème généralisé aux dérivées tangentielles pour l'équation parabolique, Bull. Acad. Pol. Sc. 8 (1960), pp. 365-371, Ricerche di Matematica 9 (1960), pp. 143-176. 
[74] Problème aux dérivées tangentielles discontinues pour l'équation elliptique, Ann. Pol. Math. 12 (1963), pp. 35-56.

[75] Sur une propriété principale d'une classe $\mathfrak{S}_{a}^{u}$ des fonctions discontinues pour le système d'arcs, Bull. Acad. Pol. Sc. 8 (1960), pp. 359-364.

[76] Sur une classe des fonctions discontinues et une intégrale singulière dans l'espace, Bull. Acad. Pol. Sc. 8 (1960), pp. 445-451.

[77] Transformations des intégrales itérées singulières dans l'espace, Bull. Acad. Pol. Sc. 9 (1961), pp. 69-74.

[78] О свойствах сингулярного интеграла в пространстве и их применении $\kappa$ одной системе сингулрных интегральных уравнений, Проблемы механики сплошной среды, Изд. Акад. Наук, 1961, рр. 288-301.

[79] Замечания, касаючиеся работы ,Исследования интегралов параболического уравнения и краевых задач в неограниченной областис, Матем. Сбор. (53), (95) (1961), pp. 539-543.

[80] Problème linéaire aux dérivées tangentielles discontinues pour une fonction harmonique dans l'espace, Bull. Acad. Pol. Sc. 9 (1961), pp. 357-362.

[81] Propriétés des intégrales itérées singulières dans l'espace, Bull. Acad. Pol. Sc. 9 (1961), pp. 713-719.

[82] On the properties of a singular integral in space and their application to a system of singular integral equations, Problems of Continuum Mechanics, Philadelphia, 1961, pp. 327-341.

[83] L'activité scientifique de la section des équations intégrales de l'Institut Mathématique de l'Académie Polonaise des Sciences, Résumé de la conférence faite à l'Institut Henri Pcincaré, le 19 Avril 1961.

[84] Sur quelques propriétés des potentiels généralisés et un problème aux limites pour l'équation elliptique, Ann. Pol. Math. 11 (1961), pp. 177-197.

[85] Problème généralisé aux dérivées tangentielles discontinues pour une fonction harmonique dans l'espace, Ann. di Mat. pura ed applicata 56 (1961), pp. 313-328.

[86] Sur certaines propriétés des intégrales analogues aux potentiels et un problème aux limites pour l'équation parabolique, Ricerche di Matem. 10 (1961), pp. 173-213.

[87] Sur certains problèmes aux limites discontinues d'ordre supérieur dans la théorie des fonctions analytiques, Ann. Pol. Math. 12 (1962), pp. 1-15.

[88] Etude de la continuité des solutions du système parabolique dépendant d'un paramètre, Ac. Nazionale dei Lincei, Serie VIII, 32 (1962), pp. 891-898 and 33 (1962), pp. 22-30.

[89] Equations paraboliques et propriétés des leurs solutions, Conf. del Sem. di Mat. tell'Universita di Bari, 1962, Bologna-Nicola Zanichelli Editore. 
[90] Sur un problème de la théorie des processus stochastiques, Zastosow. Mat. 7 (1963), pp. 125-131.

[91] Recherches sur la continuité régulière du potentiel de charge spatiale relatif aux système parabolique, Bull. Acad. Pol. Sc. 11 (1963), pp. 105-110.

[92] Etude d'un problème aux limites pour le système parabolique d'équations aux dérivées partielles, Ann. Sc. Ec. Norm. Sup., Paris 1963.

\section{Textbooks and Monographs}

\section{In Polish}

[1] Geometria analityczna (Analytic Geometry), 478 pp., I-V ed. Warszawa 1931-1959.

[2] Analiza matematyczna. T. I. Ciągi i szeregi, rachunek różniczkowy (Calculus, Vol. I. Sequences, series, differential calculus), 227 pp., I-V ed., Warszawa 1938-1956.

[3] Analiza matematyczna. T. II. Rachunek calkowy, zastosowania geometryczne analizy (Calculus, Vol. II. Integral calculus, geometric applications), 308 pp., I-V ed., Warszawa 1938-1956.

[4] Analiza matematyczna. T. III. Całki wielokrotne, równania różniczkowe zwyczajne (Calculus, Vol. III. Multiple integrals, ordinary differential equations), 202 pp., I-V ed., Warszawa 1938-1956.

[5] Analiza matematyczna. T. IV. Funkcje zmiennej zespolonej, równania różniczkowe cząstkowe, rachunek wariacyjny, rachunek operatorowy (Calculus. Vol. IV. Analytic functions, partial differential equations, variational calculus, operational calculus), 400 pp., I-II ed., Warszawa 1951-1956.

[6] Równania cakkowe i ich zastosowania. T. T. Własności ogólne równań Fredholma i Volterry (Integral equations and their applications. Vol. I. General properties of Fredholm and Volterra equations), 150 pp., Warszawa 1953.

[7] Równania calkowe $i$ ich zastosowania. T. II. Układy równań calkowych, równania całkowe nieliniowe, zastosowania równań całkowych w teorii równań różniczkowych (Integral equations and their applications. Vol. II. Systems of integral equations, nonlinear integral equations, applications of integral equations to differential equations), $192 \mathrm{pp}$., Warszawa 1958.

[8] Równania calkowe $i$ ich zastosowania. T. III. Równania całkowe mocno osobliwe, zagadnienia brzegowe $w$ teorii funkcji analitycznych (Integral equations and their applications. Vol. III. Strongly singular integral equations, boundary problems in the theory of analytic functions), 288 pp., Warszawa 1960. 
[9] Rachunek operatorowy $i$ przeksztalcenie Laplace'a (Operational calculus and Laplace transforms), 150 pp., Warszawa $19 \tilde{50}$.

[10] Zarys rachunku prawdopodobieństwa $i$ teorii blędów (An outline of calculus of probabilities and the theory of errors), $130 \mathrm{pp}$., Warszawa 1948. - [11] Równania calkowe $i$ ich zastosowania. T. IV (Integral equations and their applications. Vol. IV), in preparation.

\section{In English}

[12] Integral equations and their applications, in preparation. 